Research, part of a Special Feature on Sustainable Land-Use Practices in Mountain Regions: Integrative Analysis of Ecosystem Dynamics Under Global Change, Social-Economic Impacts, and Policy Implications

\title{
Modeling Social-Ecological Feedback Effects in the Implementation of Payments for Environmental Services in Pasture-Woodlands
}

\author{
$\underline{\text { Robert Huber }}^{l}, \underline{\text { Simon Briner }}^{2}, \underline{\text { Alexander Peringer }}^{3,4}, \underline{\text { Stefan Lauber }}^{l}, \underline{\text { Roman Seidl }}^{5}, \underline{\text { Alexander Widmer }}^{6}, \underline{\text { Francois Gillet }}^{3,7}$ \\ ${ }^{3,7}$, Alexandre Buttler ${ }^{3,7}$, Quang Bao Le ${ }^{5}$ and Christian Hirschi ${ }^{6}$
}

\begin{abstract}
An effective implementation of payment for environmental services (PES) must allow for complex interactions of coupled social-ecological systems. We present an integrative study of the pasture-woodland landscape of the Swiss Jura Mountains combining methods from natural and social sciences to explore feedback between vegetation dynamics on paddock level, farm-based decision making, and policy decisions on the national political level. Our modeling results show that concomitant climatic and socioeconomic changes advance the loss of open grassland in silvopastoral landscapes. This would, in the longer term, deteriorate the historical wooded pastures in the region, which fulfill important functions for biodiversity and are widely considered as landscapes that deserve protection. Payment for environmental services could counteract this development while respecting historical land-use and ecological boundary conditions. The assessed policy feedback process reveals that current policy processes may hinder the implementation of PES, even though a payment for the upkeep of wooded pasture would generally enjoy the backing of the relevant policy network. To effectively support the upkeep of the wooded pastures in the Jura, concomitant policy changes, such as market deregulation, must also be taken into account.
\end{abstract}

Key Words: agent-based modeling; dynamic modeling; feedback; human-environment systems; integrated study; payments for environmental services; policy network analysis

\section{INTRODUCTION}

Payments for environmental services (PES) are seen as one of the key mechanisms to regulate the use of ecosystem goods and services (EGS) by translating external, nonmarket values of the environment into financial incentives for local actors (MEA 2005, Engel et al. 2008, Sommerville et al. 2009). If well-meant management options and policy measures fail to provide the necessary financial incentives, the value of EGS is likely to be ignored in the actual decision making processes (Daily et al. 2009). The effectiveness of PES depends on the interactions between the natural environment, land-users' decision making, and the political implementation of the PES instruments as part of a broader policy scheme (Jack et al. 2008, Kinzig et al. 2011). Environmental and socioeconomic linkages, however, result in complex social-ecological systems that can only be addressed by a holistic approach combining integrated and specialized research (Carpenter et al. 2009a, Fraser et al. 2011). There exists a tradition of different frameworks on how to address such complex interactions (Folke 2006, Liu et al. 2007, Daily et al. 2009, Ostrom 2009, Alberti et al. 2011, Collins et al. 2011, Scholz 2011). All these frameworks refer to inter- and transdisciplinary research as the key to overcome fundamental problems in the analysis of such complex systems. Thereby, an explicit consideration of reciprocal feedback effects from changing socioeconomic and political conditions on ecological system changes, e.g., climate change, is an important task in interdisciplinary research (Cumming et al. 2006, Steffen 2009, Müller et al. 2010).

In our study, the outcome of feedback effects in a complex human-environmental or social-ecological system is illustrated with the example of PES to maintain a silvopastoral landscape in the Swiss Jura Mountains. These landscapes exemplarily represent a complex social-ecological system in which natural vegetation dynamics and farm management are intrinsically interdependent as is common in agricultural systems (Ericksen 2008). Silvopastoral landscapes are known to have a rich biodiversity (Buttler et al. 2009) and are more resilient to climate change impacts than other pastoral systems (Gavazov et al. 2013). However, these ecosystems are very sensitive to changes in land-use intensity because the balanced state of semiopen landscapes depends on complex interactions between herbaceous and woody plant species (Gillet 2008). In our case study region, current land-use is seen as inadequate for the maintenance of the forest-grassland mosaic of

\footnotetext{
${ }^{1}$ Swiss Federal Institute for Forest, Snow and Landscape Research WSL, ${ }^{2}$ ETH Zurich, Agri-food and Agri-environmental Economics Group, Department of Environmental Systems Science, ${ }^{3}$ Ecole Polytechnique Fédérale de Lausanne EPFL, School of Architecture, Civil and Environmental Engineering ENAC, Laboratory of ecological systems ECOS, ${ }^{4}$ University of Stuttgart, Institute of Landscape Planning and Ecology ILPOE, ${ }^{5}$ ETH Zurich, Natural and Social Science Interface, Department of Environmental Systems Science, ${ }^{6}$ ETH Zurich, Environmental Policy and Economics, Department of Environmental Systems Science, ${ }^{7}$ Université de Franche-Comté-CNRS, UMR 6249 Chrono-environnement
} 
mountain pastures because climate change disturbs the balance between grassland productivity and tree species establishment (Peringer et al. 2013).

Thus, the research questions we addressed are threefold. What long-term effect on vegetation dynamics can be expected from interlinked climate and socioeconomic changes in land use? Can payments for PES support the maintenance of silvopastoral landscapes and the corresponding EGS in the Swiss Jura Mountains? How does the relevant policy network support or oppose necessary policy decisions?

There exists a range of studies on social-ecological interactions in pastoral regions. From a review of 10 case studies worldwide, Dong et al. (2011) concluded that fragile pastoral ecosystems are becoming increasingly vulnerable because of the effects of climate change. In the context of European mountain areas, research is focusing on the aspect of land abandonment and corresponding reforestation (Keenleyside and Tucker 2010). With respect to wooded pastures, the literature has focused thus far mainly on ecological dynamics and has treated management and policy measures as exogenous (Buttler et al. 2009). These studies point toward challenges at the interface between forestry and agriculture with respect to sustainable development of humanenvironmental systems. They pave the way for integrative management (Barbezat and Boquet 2008) but, to our knowledge, none of these studies model the feedback loop between environmental and economic changes and the relevant policy decisions.

\section{ANALYTICAL FRAMEWORK}

\section{Conceptualized feedback-loop system}

The framework in this study is based on the integrated research approach as applied in the Mountland project (Huber et al. $2013 a$ ). The core of the project explicitly considers different feedback between ecosystem dynamics, socioeconomic assessment of EGS, and policy options (Huber et al. 2013b). In this contribution, we focus on two key interrelated feedback loops: (1) a primary feedback loop between aggregated landuse allocation at farm level and the potential fodder supply of the pasture-woodland landscape; (2) a secondary, yet policymediated feedback that links the long-term and qualitative changes in pasture-woodland to specific policy options and their political feasibility given the current Swiss agricultural policy network. The implementation of the policy options, in turn, determines farm structural change that eventually reshapes land-use allocation at the paddock level, i.e., the smallest grazing management unit. Figure 1 illustrates the two interrelated feedback loops addressed.

The primary feedback loop arises from farm structural change, i.e., change in size, intensity, or production activities including farm cessation, induced by policy and market changes or individual management decisions at farm level leading to changes in stocking density on paddock level. At the same time, climate change alters the natural conditions for vegetation dynamics. The combined changes in stocking density and natural conditions will influence the pastoral value on the different management units. These changes again will force the farmer to reconsider his/her land management. This feedback loop is inherent and occurs regularly, forming a primary human-environmental interrelationship between the silvopastoral system and the farming agents (primary feedback in Fig. 1). We achieved the primary feedback loop by coupling two dynamic simulation models: the spatially explicit ecosystem model of wooded pastures, WoodPaM, and the agent-based land allocation model, ALUAM-AB.

The primary feedback loop is also an important part of the secondary loop. This second feedback loop involves the longterm impacts on pasture-woodlands given a loss of the corresponding ecosystems. Political processes play a crucial role in realizing this feedback loop: the loop will only be closed if the political system recognizes the ecosystem degradation and is willing and able to respond adaptively/strategically with alternative policies, e.g., PES schemes.

We adopted a policy network approach to assess relevant policy processes and their potential impact on policy outputs (Knoke 2011). Based on concepts developed in sociology, the approach seeks to identify structural configurations resulting from exchanges, such as interactions, the flow of resources, information provision, etc., between the actors in the policy network, which, in turn, constrain or enable specific policy outputs (Sandström and Carlsson 2008). In the context of ecological changes in the wooded pasture system and farmlevel structural changes in the Jura Mountains, the main relevant policy network is associated with the Swiss federal agricultural policy. Farmers in the Jura Mountains have been heavily dependent on direct payments guaranteed by federal agricultural policy for the upkeep of grazing in wooded pastures where access is relatively difficult and soils are often rather thin. Therefore, both the ecological and socioeconomic conditions in the Jura Mountains depend significantly on the way in which the federal agricultural policy network perceives and values the wooded pasture system, its dynamics, and the structural situation for farmers in the region. This way, the agricultural policy network mediates feedback from the wooded pasture system to the farm level and, if adequate political measures are supported by the network, allows the long-term deterioration of pasture-woodlands to be counteracted politically (secondary feedback in Fig. 1).

When analyzing this second feedback process, there are different policy options that must be assessed with respect to their ecological-economical effectiveness, political feasibility, and social relevance. Therefore, we used ALUAM-AB to implement a consistent set of policy options giving due consideration to the structure of the relevant policy network 
Fig. 1. The conceptual framework of a complex human-environment system with a focus on social-ecological feedback loops and adaptation in response to policy processes and instruments, as well as climate and market changes. Note: Rectangular boxes are the subsystems whose dynamics are endogenously represented by the study. Text with no outline are ecological or social processes that genuinely form the feedback loops. Circular boxes are factors considered external in this study.

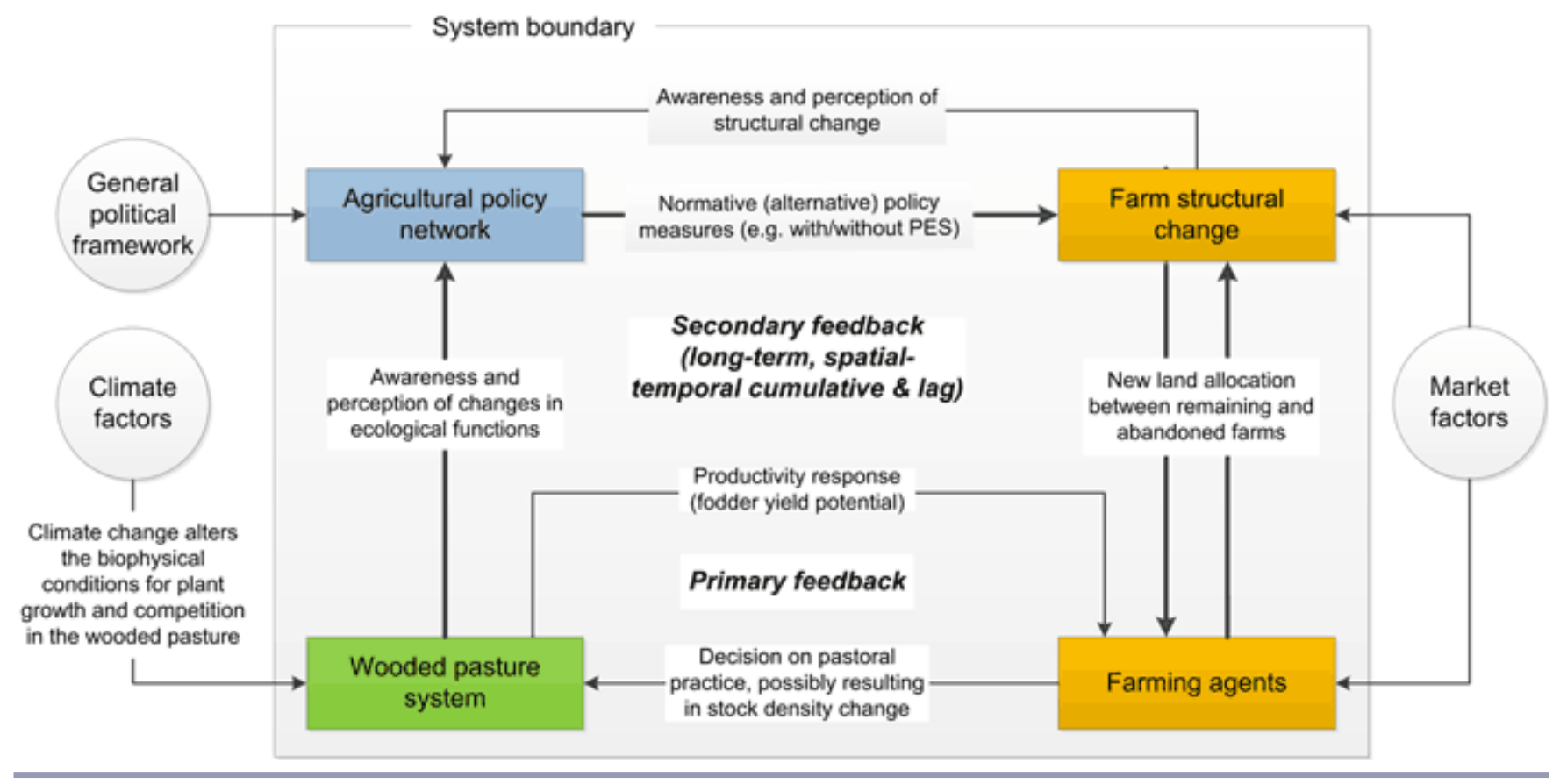

in the Swiss agricultural sector in a policy scenario that, in a next step, will be re-examined to assess its effects on the individual behavior of the farmers. In the long term, farm structure can shift substantially in response to policy and market driving forces as well as in response to temporally cumulative changes in farm resource structure. Changes in farm structure will reshape the land-use decisions of farm agents through the modification of the decision context.

\section{Policy scenarios}

Domestic public support for agriculture in Switzerland is still one of the highest worldwide. Border protection measures and direct payments remunerating farmers for specific services of public interest result in an estimated producer support of $60 \%$ (OECD 2010).

An important question is how different policy instruments should be combined to achieve conservation objectives because in a world in which several sources of market failure coexist, a combination of instruments is essential (Engel et al. 2008). From an economic perspective, trade distortions should be reduced (Anderson 2010), whereas the support for specific services of public and common interest should focus on targeted and tailored payments (Wunder et al. 2008). According to this literature, targeted, green box compatible payments for the maintenance of silvopastoral landscapes would allow for a specific remuneration of farmers' efforts toward the upkeep of wood-pastures and corresponding environmental services. Such payments for environmental services (PES) are seen as the way toward integrating ecosystem goods and services in the actual policy making process (Engel et al. 2008). However, PES cannot be evaluated in isolation. Their impact depends strongly on the concomitant design of other agricultural policy measures. Thus, we defined two policy scenarios based on different levels of PES (Table $1)$ :

The protection scenario is a continuation of the existing policies. In this scenario, domestic support for the agricultural sector remains at current levels. However, payments based on the number of animals are reduced as decided in the most recent policy reform process (Lanz 2012). More importantly, market access remains restricted including tariffs and import quotas for grains and meat, respectively, resulting in the maintenance of current higher farm gate prices.

The PES scenario is a new scenario that includes payments for environmental services (PES). In this scenario, domestic support, i.e., direct payment system, is reformed with a focus on ecological performance without increasing the overall level of payments. With respect to market access, the level of support in Swiss agriculture is reduced. Prices for agricultural commodities decline significantly. Thus, this scenario is compatible with the international WTO regime (WTO 2011). 
Table 1. Instruments in the two considered policy scenarios: "Protection" and "Payment for environmental services (PES)."

\begin{tabular}{|c|c|c|}
\hline & Protection & PES \\
\hline \multicolumn{3}{|l|}{ Market access } \\
\hline Border protection (tarifs, import quotas) & maintained at current levels & reduced \\
\hline \multicolumn{3}{|l|}{ Domestic support } \\
\hline \multicolumn{3}{|l|}{ Blue box } \\
\hline Payments per output (head / crops) & reduced & abolished \\
\hline \multicolumn{3}{|l|}{ Green box } \\
\hline Payments based on acreage (cross compliance) & continued & continued \\
\hline Ecological payments (e.g., for less intensive land use) & continued & increased \\
\hline Upkeep of wooded pastures: acreage payments for minimal stocking density & absent & introduced \\
\hline
\end{tabular}

These policy scenarios are combined with the scenario B2 of moderate future climate change as proposed by the Intergovernmental Panel on Climate Change (IPCC 2000). Monthly time series for temperature and precipitation are used for simulation of vegetation dynamics in WoodPaM based on the regionalization of climate data estimated for the B2 scenario from 2001 until 2100 (for methodological aspects see Briner et al. 2012). The B2 scenario is oriented toward environmental protection and social equity and focuses on local and regional levels (Abildtrup et al. 2006). Hence, agricultural policy is assumed to aim at self-sufficiency, and ecological stewardship is important (Verburg et al. 2010). Both characteristics, i.e., self-sufficiency and ecological stewardship, are essential aspects in our policy scenarios. Thus, they represent a possible policy state in line with the overarching story lines of the IPCC.

\section{Case study region}

In the Swiss Jura Mountains, intensive land-use forms are closely associated with extensively grazed summering pastures. We studied a local community of eight farmers who cultivate a total of $390 \mathrm{ha}$. A description of the different farm households is given in Table A2 (Appendix 1). Although the local land market comprises all farm land, the effects of landuse change is only simulated on wooded pastures, which consist of 69 different paddocks with an average size of 2.39 ha. Sixty paddocks are located around the two villages Les Planets and Les Cluds (124 ha at $1200 \mathrm{~m}$ a.s.l.) and are used quite intensively, and nine paddocks form the summering pasture of La Bullatonne at a higher elevation (41 ha at 1300 $\mathrm{m}$ a.s.l). Because of spatial separation, vegetation dynamics modeling is carried out separately for Planets-Cluds and Bullatonne.

\section{METHODS}

\section{Agent-based socioeconomic modeling: ALUAM-AB}

Agent-based modeling (ABM) offers the opportunity to link human-environmental systems and to include specific individual behavior in the ecosystem as well as the human decision making (An 2012). Particularly with respect to interdisciplinary research questions, $\mathrm{ABM}$ is a widely used tool at the human environment interface and has also become state-of-the-art in addressing land-use change dynamics (Parker et al. 2003, Matthews et al. 2007, Le et al. 2008, Heckbert et al. 2010). With respect to European agriculture, different agent-based models have emerged in recent years focusing on structural change (Happe et al. 2006, 2008), impact assessment of innovations and policies (Berger 2001), or farmer-environment interactions (Roeder et al. 2010, Valbuena et al. 2010, Schreinemachers and Berger 2011).

Following these models, we created ALUAM-AB (ALUAMAgent-Based) to achieve a better understanding of agricultural land-use changes triggered by market and policy changes while also considering farmers' individual preferences. Proceeding in annual time steps, the model simulates structural change at farm level as an endogenous development of prices, policies, and individual preferences, which are given exogenously. Spatio-temporal land-use patterns, i.e., dynamic land-use intensity at paddock level, emerge as the main outcome of the structural changes at farm level and allow for a sound linkage with the vegetation model WoodPaM at paddock and landscape levels. Given the focus on the individual characteristics of the farmers in our approach, the temporal scale of the model is limited to 25 years.

The structure of ALUAM-AB represents the coupled socialecological system in the silvopastoral area being studied. The model consists of an interlinked human and environment subsystem. Appendix 1 contains a detailed description of the model in accordance with the overview, design concepts, and details (ODD) protocol for describing agent-based models (Grimm et al. 2006, 2010).

The model is defined by interconnected human and environmental/agronomic subsystems. The human subsystem is defined by individual farm agents acting as interactive 
decision making loci. A farm agent has (1) its own state, which is updated after every simulation period of one year and (2) decision making mechanisms for managing farm resources. We utilized the structure of the agricultural sector model ALUAM (Briner et al. 2012) by adaptively downscaling it from agricultural sector level to individual farm level.

The state of the farm agent includes variables for household composition and available resources, i.e., land, capital, and labor, and household preferences for agricultural activities. The individual farmer's preferences considered in the model are summarized in Table A2 (Appendix 1). They include every farmer's willingness to (1) increase farm size, i.e., growth, (2) participate in agri-environmental schemes, i.e., extensification, (3) diversify farm activities, i.e., activity change, and (4) specific preferences, e.g., for work load. Data for the agents' variables were collected through semistructured face-to-face interviews with farmers in the case study area.

The agents' decision mechanism is represented by an income optimization approach on farm level that governs the allocation of the agents' available resources to production considering natural, farm-level, and individual constraints as well as incentives and regulations from the market and policy scenarios. Although the general structure and algorithm of the optimization submodel are common to all farm agents, its vectors of input variables and parameters, e.g., household's preference coefficients for agriculture activities are specific to agent types that are defined by farm size, livestock, and production systems. Existing capacities are considered as sunk costs representing path dependencies on the individual farms. Economic interactions among the farm agents are represented by a land market module that was described in detail by Lauber $(2006 a, b)$. In general, land allocation is based on shadow prices and the socioeconomic characteristics of the farms (Fig. A1 in Appendix 1).

The environmental/agronomic subsystem is characterized by the agricultural production landscape in the case study area, of which the smallest landscape units are the paddocks as used by the individual households. Agronomic variables include crop losses, plant nutrient requirements $(\mathrm{N}, \mathrm{P})$, manure production, and production coefficients such as fodder intake, growth, birth, deaths of animals, and labor requirements that are based on Swiss average data (Briner et al. 2012). Production-related variables are aggregated at farm level and represent aggregated values over one year. Natural conditions of the different paddocks and potential fodder production are integrated using results of the vegetation model WoodPaM. In the farm decision process, i.e., income optimization, the environmental variables are considered as material balances, i.e., fodder and nutrients that link land-use activities with livestock activities. As a result, land-use intensities can be defined in a spatially explicit manner. Crop rotation requirements and a labor balance are additional constraints that link the human and environmental/agronomic subsystems.

\section{Landscape dynamic modeling: WoodPaM}

The simulation model WoodPaM (Gillet 2008) was developed to investigate the successional dynamics of wooded pastures in mountain areas. WoodPaM is a spatially explicit model of pasture ecosystems that is able to simulate the emergence of a semiopen landscape structure from selective grazing by cattle. During simulations, selective foraging by cattle causes local impacts on vegetation, e.g., grazing, browsing, trampling, and dunging, which in turn and together drive the dynamics of the landscape structure with a general trend toward forest development.

In WoodPaM, a pasture is represented by a grid of $25 \mathrm{~m}^{2}$ cells. Each cell features four submodels for the herb layer, shrubs, trees, and cattle. Local vegetation succession in the herb layer is driven by local intensity of grazing and dunging, as well as by tree cover. Local woody plant succession is driven by seedling input, safe-site availability in the herb layer, and the effect of browsing cattle on tree seedlings and saplings. Local successions within cells are coupled to neighboring cells by seed dispersal from trees and are coupled at paddock level by cattle behavior. Selective foraging by cattle at pasture level considers the attractiveness of grid cells, which is mainly given by forage production as the attractor, as well as by tree cover and geomorphology, e.g., slope, rock outcrops, as repellents. The simulated landscape structure is visualized in maps, drawn at several time steps, and based on classes of tree cover, which represent phytocoenosis types developed for the structural classification of pasture-woodland vegetation, i.e., unwooded pastures, sparsely wooded pastures, densely wooded pastures, and grazed forests (Gallandat et al. 1995). The classification serves to calculate aggregated changes on landscape level using a landscape aggregation index (He et al. 2000). The climate sensitivity of simulated vegetation has been refined recently (Peringer et al. 2013) on the basis of previous model versions (Gillet 2008).

When analyzing the primary feedback, we coupled the dynamics of the natural and socioeconomic systems by regularly updating interface variables between WoodPaM and ALUAM-AB. Although each model is driven by synchronized time series of climatic or agronomic constraints, farm structural change is passed from ALUAM-AB to WoodPaM in terms of numbers of livestock per paddock. Vegetation response to the stocking of paddocks is transferred from WoodPaM to ALUAM-AB in terms of forage production. This data exchange occurs every five years, starting in 2000 (see Appendix 1 for data exchange protocol) and assumes that farmers' decisions are not driven by single year conditions, for example, weather, but by a certain experience built over time, i.e., five years. 
Because ALUAM-AB is based on the characteristics of the current farmers, simulations stop in 2034. However, because of the large temporal gap between the establishment of tree seedlings and the formation of trees and forest stands, the combined effects of land-use and climate on landscape structure can only be shown in a time frame of at least a few tree generations (Bithell and Brasington 2009). Thus, we continued WoodPaM simulations until the end of currently available projections of climate change, i.e., 2100, holding the land-use intensity simulated for 2034 constant until 2100 . These exploratory simulations pinpoint the potential longterm consequences of today's land-use decisions. Without considering such long-term trends, cumulative effects of the management changes cannot be observed in the results (Wallman et al. 2005). As a consequence, our scenario results have to be interpreted as long-term trends of climate, socioeconomic, and political interactions and not as realistic predictions of the future.

\section{Social network analysis of the Swiss agricultural sector}

We assessed the political feasibility of different policy options by taking a policy network approach (Hirschi et al. 2013). Methodologically, a policy network approach first identifies the most important actors, mainly in the form of different governmental and nongovernmental organizations, in policy subsystems and then analyzes the connections between these actors using network analytical techniques (Wasserman and Faust 1994). Specifically, we empirically examined cooperative and conflictive interactions between the network actors during the agricultural policy reform process between 2007 and 2011. This was based on official documents and coded the actors' policy preferences regarding domestic support, market regulation, and greening of Swiss agricultural policy using the results of the official governmental consultation process. Based on the actor process events scheme (APES) concept (Serdült and Hirschi 2004, Widmer et al. 2008), we then aggregated the policy network structure from the systematically coded policy process (so-called affiliation or actor-event networks, see Wasserman and Faust 1994). These affiliations allowed us to reconstruct the policy network that has adopted the most recently implemented agricultural reform in Switzerland. Furthermore, to combine existing policy network structures with future policy scenarios, we reviewed the policy positions of the political actors that are embedded in the Swiss agricultural policy network and analyzed their structural position in the network using network centrality measures (Freeman 1979).

The policy network analysis of the Swiss agricultural sector displays the Federal Office for Agriculture (FOAG) and Department of Economic Affairs (DEA), the responsible ministry, and the Federal Council (FC) as the central actors in the policy network. The main sectoral interest organization, the Swiss Farmers' Association (SBV), is also centrally positioned in the network with close connections to both the executive branch of the Swiss federal government and the two chambers of the federal parliament. When it comes to the policy positions of the actors, however, the SBV adopts a rather oppositional attitude toward several issues in official Swiss agricultural policy as represented by FOAG, DEA, and FC.

\section{RESULTS}

\section{Land-use change and vegetation dynamics under climate change}

In the protection scenario, the amount of land grazed by more than one livestock unit per ha decreased by $24 \%$. In contrast, land with a low stocking density increased by $5 \%$ (Table 2 ). This development can be derived from the assumed reduction of per-capita payments per animal, which motivates farmers to lower the absolute number of animals. At the same time, high acreage-based payments ensure that no land is abandoned by farmers, and the whole area is still cultivated. In Les Planets-Cluds, this combination of decreasing numbers of livestock and a constant area leads to reduced stocking densities on the least suitable paddocks. Consequently, in the long run of the protection scenario, densely wooded pastures spread, and all of the formerly unwooded pastures develop sparsely wooded pastures at least (Fig. 2). Open grassland would disappear in the case study region, although until 2034, only minor changes would be recognizable (Table 3 ). Thus, the consequences of more extensive stocking rates cannot be observed in the medium term. In the case of La Bullatonne (Fig. 3), which is characterized by lower stocking densities at the beginning of the simulation, this successional trend is even more pronounced. For 2100, our simulation shows a homogenization of the landscape in which densely wooded pastures and sparsely wooded pastures predominate (Table 4).

Table 2. Change in simulated agricultural land-use intensities between 2010 and 2034. PES = Payment for environmental services.

\begin{tabular}{lccc}
\hline \hline & Year & $\begin{array}{c}\text { Low stocking density } \\
(<1 \mathrm{LU} / \mathrm{ha})\end{array}$ & $\begin{array}{c}\text { High stocking density } \\
(>1 \mathrm{LU} / \mathrm{ha})\end{array}$ \\
\hline & 2010 & $107 \mathrm{ha}$ & $48 \mathrm{ha}$ \\
Scenario Protection & 2034 & $112 \mathrm{ha}$ & $36 \mathrm{ha}$ \\
\% change & & $+5 \%$ & $-24 \%$ \\
$\begin{array}{l}\text { Scenario PES } \\
\text { \% change }\end{array}$ & 2034 & $92 \mathrm{ha}$ & $54 \mathrm{ha}$ \\
& & $-14 \%$ & $+13 \%$ \\
\hline
\end{tabular}

Land-use intensities increase in the PES policy scenario with payments for ecosystem maintenance and concomitant reductions in market protection. In contrast to the protection scenario, the amount of land grazed with a stocking density of more than one livestock unit per ha increased by $13 \%$ and less intensively used land decreased by $14 \%$ (Table 2 ). As a consequence of the increased stocking densities, a large proportion of unwooded pastures can be maintained, 
especially in the southern part of Planets-Cluds where densely wooded pastures hardly spread (Fig. 2). This leads to an overall increase of landscape diversity as shown by a decreased landscape aggregation index in Table 3. Although in PlanetsCluds the introduction of PES in our scenario contributes effectively to the upkeep of open grassland and thus the silvopastoral mosaic, in La Bullatonne the maintenance of diverse wood pastures fails (Fig. 3). Despite an increase of stocking densities, the landscape homogenizes resembling the development in the protection scenario. This is illustrated by the increased landscape aggregation index in Table 4. In addition, the level of grazed forest in Planets-Cluds disappears in the PES scenario. This is explained by the fact that in future scenarios, the intense impact of climate change leads not only to a shift in mosaic, but also to modifications in species composition (Peringer et al. 2013). However, given the high grazing pressure in the PES scenario, the establishment of new trees, i.e., beech and pine replacing spruce, is delayed.

Fig. 2. Landscape: structural change in Les Planets-Cluds (1200 $\mathrm{m}$ a.s.l., intensive use) with the protection and payment for environmental services (PES) policy scenarios.

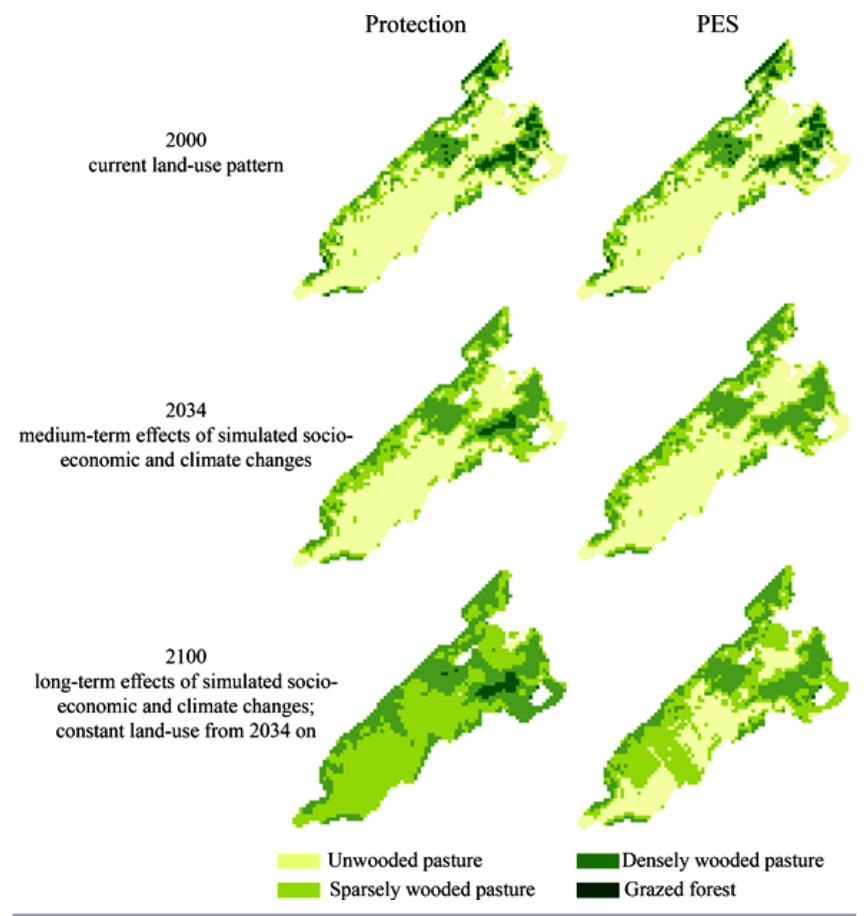

These results have two implications. First, there is a time lag in the effect of changed stocking rates on the simulated vegetation dynamics in pasture-woodlands. Although new incentives trigger a change in ecosystem management, it may take decades until desired or undesired effects appear because of the slow response at the landscape level. Thereby, land-use history plays an important role. Forest encroachment is faster in currently extensive pastures because numerous trees are already established, representing a legacy effect. Second, management changes may have ambiguous effects. On the one hand, the simulated maintenance of open grassland increases diversity on landscape level and supports specific habitats rich in biodiversity. On the other hand, open grassland is predicted to be more susceptible to climate change and high grazing pressure may slow the adaption of tree species communities to new climate conditions.

Fig. 3. Landscape: structural change in La Bullatonne (1300 $\mathrm{m}$ a.s.l, extensive use) with the protection and payment for environmental services (PES) policy scenarios.
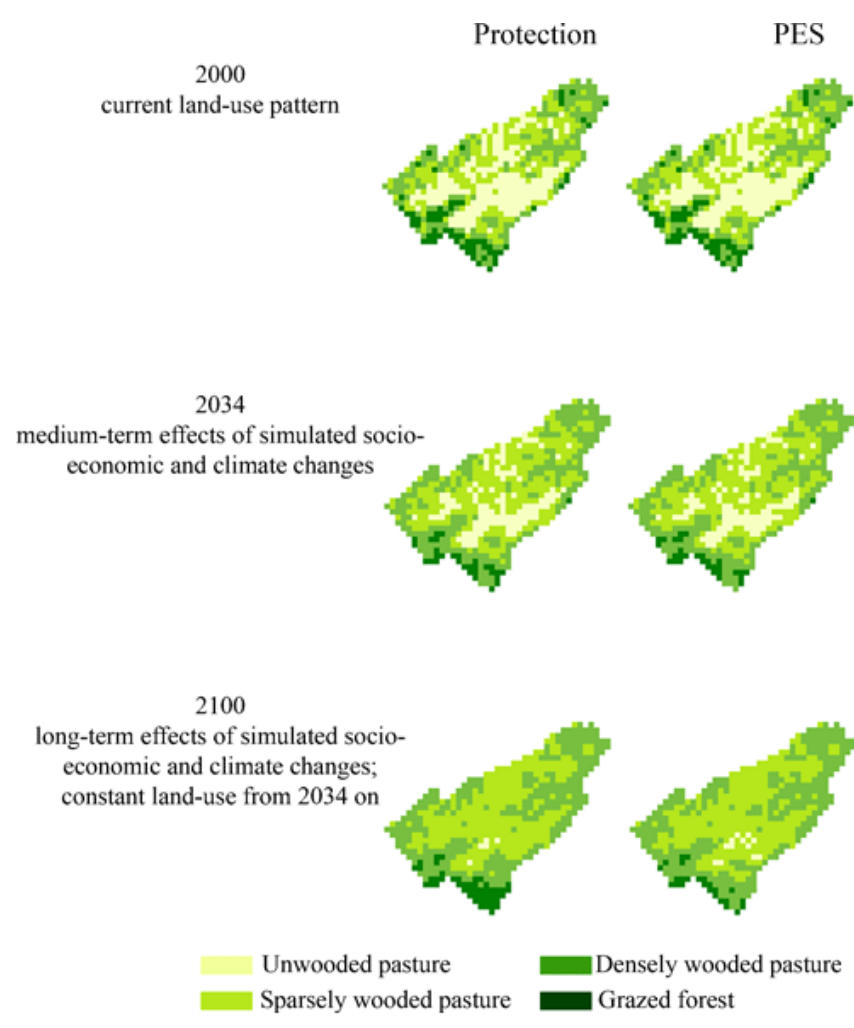

\section{Environmental awareness and policy feedback on degradation of pasture-woodlands}

Table 5 summarizes the current actors' policy positions regarding the deregulation of international agricultural markets and the support for a further greening of the agricultural sector. The main supportive actors of both the deregulation and greening scenario are found at the core of the policy network, whereas the opponents are located mostly at the periphery, with the exception of the main sectoral interest organization, the Swiss Farmers' Association (SBV; Hirschi et al. 2013). Interestingly, the SBV has an ambivalent position toward greening, meaning that its position is neither clearly 
supportive nor hostile. This ambivalence can be explained by the key policy core position of the SBV, i.e., its attempt to maintain the income level of farmers and, thus, to sustain the agricultural sector at least at its current economic size.

Table 3. Percentage of pasture woodland vegetation types and landscape aggregation index in 2000, 2034, and 2100 in the two policy scenarios for Planets-Cluds ( $1200 \mathrm{~m}$ a.s.l. intensive use). PES = Payment for environmental services.

\begin{tabular}{lccccc}
\hline \hline $\begin{array}{l}\text { Pasture- } \\
\text { woodland } \\
\text { vegetation } \\
(\%)\end{array}$ & $\begin{array}{c}\text { Unwooded } \\
\text { pastures }\end{array}$ & $\begin{array}{c}\text { Sparsely } \\
\text { wooded } \\
\text { pastures }\end{array}$ & $\begin{array}{c}\text { Densely } \\
\text { wooded } \\
\text { pastures }\end{array}$ & $\begin{array}{c}\text { Grazed } \\
\text { forests }\end{array}$ & $\begin{array}{c}\text { Landscape } \\
\text { aggregation } \\
\text { index } \\
\text { (AIL) }\end{array}$ \\
\hline $\begin{array}{l}2000 \\
\text { Scenario Protection }\end{array}$ & 61.4 & 14.8 & 18.2 & 5.6 & 0.6809 \\
2034 & 51.1 & 24 & 23.7 & 1.3 & 0.7227 \\
2100 & 1.5 & 65.1 & 31.1 & 2.3 & 0.8103 \\
Scenario PES & 53.3 & 22.3 & 24.3 & 0 & 0.7268 \\
2034 & 40.7 & 34 & 25.3 & 0.1 & 0.7193 \\
2100 & & & & & \\
\hline
\end{tabular}

Table 4. Percentage of pasture woodland vegetation types and landscape aggregation index in 2000, 2034 and 2100 in the two policy scenarios for La Bullatonne (1300 m a.s.l. extensive use). PES = Payment for environmental services.

\begin{tabular}{|c|c|c|c|c|c|}
\hline $\begin{array}{l}\text { Pasture- } \\
\text { woodland } \\
\text { vegetation } \\
(\%)\end{array}$ & $\begin{array}{l}\text { Unwooded } \\
\text { pastures }\end{array}$ & $\begin{array}{l}\text { Sparsely } \\
\text { wooded } \\
\text { pastures }\end{array}$ & $\begin{array}{l}\text { Densely } \\
\text { wooded } \\
\text { pastures }\end{array}$ & $\begin{array}{l}\text { Grazed } \\
\text { forests }\end{array}$ & $\begin{array}{l}\text { Landscape } \\
\text { aggregation } \\
\text { index } \\
\text { (AIL) }\end{array}$ \\
\hline 2000 & 29.6 & 32.1 & 27.8 & 10.5 & 0.5196 \\
\hline \multicolumn{6}{|c|}{ Scenario Protection } \\
\hline 2034 & 17.1 & 42.6 & 35.6 & 4.7 & 0.5995 \\
\hline 2100 & 0.8 & 46.6 & 45.2 & 7.5 & 0.7439 \\
\hline \multicolumn{6}{|c|}{ Scenario PES } \\
\hline 2034 & 15.6 & 42.9 & 36.8 & 4.7 & 0.6014 \\
\hline 2100 & 1.8 & 47.5 & 46.9 & 3.8 & 0.7187 \\
\hline
\end{tabular}

Consequently, the SBV could support a greening scenario if it resulted in a continuation or even an expansion of direct payments for the agricultural sector. However, it opposes greening if the consequences would mean a switch from production oriented to a purely ecologically based direct payment system. The SBV is strongly opposed to the deregulation scenario and is supported by the conservative right-wing Swiss People's Party (SVP), which also takes a clear stance against new ecological standards for the agricultural sector. These results can be seen as an indication that the agricultural sector would be willing to support more targeted ecological policy instruments, as central in the PES scenario, as long as production oriented support is not abolished on a large scale, and the current economic significance of the agricultural sector can, at the very least, be maintained.

\section{DISCUSSION}

There is an increase in the literature on complex system analysis addressing interlinked environmental and social problems (Scholz 2011). Our results illustrate an integrated research approach assessing two different feedback loops in modeling human-environment interactions, taking into account climate and land-use changes. A farm survey, to collect farmers' current attitudes and preferences, allowed an interdisciplinary model-based assessment of future landscape development that is rooted in the empirical realities of the case study area.

Our scenario analysis faced two challenges referring to the spatial and the temporal scale of our integrative modeling approach. First, the study area was small (390 ha) and only a limited number of farm agents were represented in the model. The reason for not choosing a sectoral perspective was that we wanted to match the represented decision making with the level of detail in the fine scale vegetation model. The latter, in turn, is limited to a small region because of computational constraints. This somewhat restricts the representativeness of our conclusions even if the farmers represented are very typical for the Swiss Jura Mountains.

Second, the timescales of the two models are different. On the one hand, ALUAM-AB should not be run over a longer time period because there is large uncertainty regarding the behavior of the next generation of land users. Thus, in a longer term simulation, we would lose one of the strengths of our modeling approach, the anchoring of socioeconomic decisions in the empirical realities of the farmers. On the other hand, expanding the time horizon in WoodPaM makes sense because it allows the taking into account of the inertia of the tree populations in response to climate change and pastoral management decisions to capture land-use legacies (Foster et al. 2003). The landscape patterns in 2034 substantially affect the landscape development simulated by WoodPaM in the subsequent 65 years. This path dependency ensures that the results of ALUAM-AB in the first 35 years shape the longterm landscape pattern.

We are aware that there are uncertainties in the representation of future human decision making and the corresponding simulation of scenarios (Carpenter et al. 2009b). Thus, our trajectories of future developments should not be interpreted as predictions, but as plausible accounts of the future (Carpenter et al. 2006). In addition, scale mismatches between social and ecological systems are widespread and not avoidable in social-ecological system research (Cumming et al. 2006). Our study demonstrated an approach to integrate different scales into the analysis, but could not avoid this scale mismatch problem, which remains open for future research (Rounsevell et al. 2012). Nevertheless, we think the approach presented is a step in the right direction in the analysis of socialecological feedback effects. 
Table 5. Policy positions of core actors in the Swiss agricultural policy network.

\begin{tabular}{lcc}
\hline \hline & $\begin{array}{c}\text { Deregulation of international } \\
\text { agricultural market }\end{array}$ & $\begin{array}{c}\text { Support of greening of agricultural } \\
\text { sector }\end{array}$ \\
\hline Trade Associations & Strongly supportive & Indifferent \\
Swiss Federal Council (FC) & Supportive & Supportive \\
Federal Office of Agriculture (FOAG) / Federal Department of & & \\
Economic Affairs, Council of State (DEA) / Majority of Parliamentary & & \\
Committees on Economy and Dues NC & Strongly opposed & Ambivalent \\
Swiss Farmers' Association (SBV) & Strongly opposed & Strongly opposed \\
Swiss People's Party (SVP) & & \\
\hline
\end{tabular}

Fundamentally, the policy network analysis allowed for a reality check of our policy recommendations. Without this knowledge about the political feasibility, there is a risk that the necessary incentives, even if scientifically sound, may be rejected early in the policy process. Obviously, such knowledge does not eliminate the need for political negotiations. Science-based, so-called first best policy solutions hardly enter the political process without objections from some fraction of the political spectrum. However, a better knowledge and understanding of the existing political conditions as displayed in a policy network allows the identification of constellations, opportunities, and strategies that are likely to ease the formulation of policy measures that are politically feasible.

\section{Long-term vegetation dynamics driven by climatic and socioeconomic changes}

Climate change, under a moderate warming scenario, is predicted to lead to a further segregation of woodland and grassland in the Jura Mountains (Peringer et al. 2013). Our study suggests that this trend is encouraged by medium-term socioeconomic interactions that result in less intensive land use. Even though the evaluation of feedback effects revealed important spatial differences leading to a loss and a gain of habitats in different locations, as also shown by Claessens et al. (2009), the model-based assessment of wooded pastures foresees less heterogeneity and overall, an increase in homogenized land cover categories in the long run. Thus, the future trend is expected to reduce ecosystem diversity in our case study region. This result is in line with different assessment studies in mountain regions (MEA 2005, EEA 2010) and scenario analyses (Verboom et al. 2007, Pereira et al. 2010, Verburg et al. 2010).

The extent of the loss in various habitats depends on different ecological and socioeconomic boundary conditions represented in our scenarios. Vegetation dynamics accelerated with extreme climate change scenarios (Peringer et al. 2013). Land-use change depends on the specific policy scenario and farm types analyzed, as also shown by Hanley et al. (2012). In addition, historical and current land use, as well as past disturbances such as wind throw (Chételat et al. 2013), may have triggered vegetation dynamics that cannot be reverted because of a legacy effect (Foster et al. 2003, Liu et al. 2007, Sitzia and Trentanovi 2011). Thus, even a rational economic policy setting may be unable to ensure the maintenance of the pasture-woodland landscape in its existing form. This reveals the importance of interdisciplinary frameworks in assessing mountain landscape change and the corresponding environmental impacts (Gibon et al. 2010, Figueiredo and Pereira 2011).

In addition to intensification or land abandonment as drivers of biodiversity loss (Zimmermann et al. 2010), we argue that in wooded pastures an underuse also contributes to the loss of important habitats. Wooded pastures are conspicuously prone to land-use extensification, which is, in general, seen as a promoter of biodiversity (Marini et al. 2011). This is an important aspect when discussing policy measures designed to counteract the increasing segregation of pasture-woodlands.

\section{Policy measures to support the maintenance of silvopastoral landscapes}

We assessed a potential policy alternative to mitigate this development. Given the assumption that any new policy cannot be implemented at the expense of an increased overall support for farmers, we linked a payment for environmental services scheme with a more open market policy. The modeling results revealed that the assessed PES scenario would counteract a homogenization of the landscape. However, natural processes such as succession or forest encroachment may dictate management alternatives that lead to an increased stocking density or selective logging in some sectors (Chételat et al. 2012). Because of the inevitable naturedriven structural changes in the landscape mosaic, it will neither be possible nor desirable to "freeze" existing landscape patterns with PES.

In contrast, farm structural change based on economic incentives, attitudes, and preferences of the farmers revealed a stable and predictable development over our simulation period of 25 years. This can be explained by the fact that the size of the farms is relatively large (48 ha) compared to the Swiss average (18 ha), which permits a stable income even with more open markets. Although farmers change land-use intensities to adapt to these regime shifts, they are not forced to stop production because of financial reasons. 
Considering the structure of the policy network and alignment of the policy preferences in the sector, a successful introduction of PES depends on the degree of market deregulation that accompanies these payments. Even though core actors are supportive toward a deregulation of agricultural markets, more open markets will face strong opposition from the agricultural sector itself, politically supported by the SVP. Given the strong mobilizing power of the main opponents, SBV and SVP, it seems rather unlikely that the supporters of deregulation will take the risk of an ambitious reform proposal (Hirschi et al. 2013). On the whole, the agricultural sector seems to be willing to back the process of more targeted ecological policy instruments, i.e., greening, as long as production oriented support for farmers is not abolished entirely and the economic level and significance of the agricultural sector can, at the very least, be maintained (Huber et al. 2011).

Wooded pastures are a specific case in which biodiversity conservation demands an increase of land-use intensities rather than a decrease. All things being equal, the farmers' association will certainly support any payments that increase agricultural income. However, unless the markets are more open, the introduction of PES that leads to an increase of stocking densities on farms will raise the producer support estimate and once again provoke opposition from the (federal) core actors in the policy network. Policy making organizations' environmental awareness and capacity to recognize substantial change in ecological function, as early as possible, is crucial for realizing the secondary feedback loop as expected. However, so far, there have been too few studies focusing on this aspect. Because policy measures have frequently delayed impacts (Le et al. 2010) and costs for ecological restoration are often prohibitive, it may be too late to act at the moment when unexpected qualitative changes become clearly observable. To this end, the understanding of early warning signals announcing critical social-ecological changes should be a challenging, yet fruitful and highly relevant research field.

\section{CONCLUSION}

Our results show that concomitant socioeconomic changes and climate change may accelerate the segregation between closed forest and open grassland in woodland ecosystems of the Jura, leading to losses in biodiversity. In addition, economic incentives, in the form of payments for environmental services, counteract this development but still respect historical land-use and ecological boundary conditions. The modeled feedback loop between agricultural stocking densities and pastoral value in our case study area illustrates the importance of the consideration of concomitant socioeconomic and climate change effects, thus supporting the call for an integrated assessment of land use and climate changes in human-environmental system analysis. The assessed policy feedback process revealed that concomitant policy issues might hinder implementation, even though a payment for the upkeep of wooded pastures enjoyed the backing of the policy network. To effectively support the upkeep of the wooded pastures in the Jura further policy changes, such as market deregulation, must be taken into account.

Responses to this article can be read online at: http://www.ecologyandsociety.org/issues/responses. $\mathrm{php} / 5487$

\section{Acknowledgments:}

This work was supported by the Competence Centre Environment and Sustainability of the ETH Domain, Switzerland as part of the Mountland project and by the State Secretariat for Education and Research (SER C07.0112) in the framework of the COST Action FP0603. We thank the editor in chief, the subject editor, and two anonymous reviewers for their very helpful feedback. We are also grateful to Adrian Iten, Joël Chételat, and Jean-Bruno Wettstein for their valuable support. We also thank the farmers of our case study region for their willingness to participate in our study.

\section{LITERATURE CITED}

Abildtrup, J., E. Audsley, M. Fekete-Farkas, C. Giupponi, M. Gylling, P. Rosato, and M. Rounsevell. 2006. Socio-economic scenario development for the assessment of climate change impacts on agricultural land use: a pairwise comparison approach. Environmental Science and Policy 9:101-115.

Alberti, M., H. Asbjornsen, L. A. Baker, N. Brozovic, L. E. Drinkwater, S. A. Drzyzga, C. A. Jantz, J. Fragoso, D. S. Holland, T. A. Kohler, J. Liu, W. J. McConnell, H. D. G. Maschner, J. D. A. Millington, M. Monticino, G. Podestá, R. G. Pontius, Jr., C. L. Redman, N. J. Reo, D. Sailor, and G. Urquhart. 2011. Research on coupled human and natural systems (CHANS): approach, challenges, and strategies. Bulletin of the Ecological Society of America 92:218-228. http://dx.doi.org/10.1890/0012-9623-92.2.218

An, L. 2012. Modeling human decisions in coupled human and natural systems: review of agent-based models. Ecological Modelling 229:25-36. http://dx.doi.org/10.1016/j. ecolmodel.2011.07.010

Anderson, K. 2010. The political economy of agricultural price distortions, Cambridge University Press, Cambridge, UK.

Barbezat, V., and J.-F. Boquet. 2008. Gestion intégrée des paysages sylvo-pastoraux de l'Arc jurassien. Conférence TransJurassienne, La Chaux-de-Fonds, Besançon, France. 
[online] URL: http://www.waldwissen.net/waldwirtschaft/ nebennutzung/agroforst weide/wsl gestion paturages boises/ wsl gestion paturages boises manuel.pdf

Berger, T. 2001. Agent-based spatial models applied to agriculture: a simulation tool for technology diffusion, resource use changes and policy analysis. Agricultural Economics 25:245-260. http://dx.doi.org/10.1111/j.1574-0862.2001. tb00205.x

Bithell, M., and J. Brasington. 2009. Coupling agent-based models of subsistence farming with individual-based forest models and dynamic models of water distribution. Environmental Modelling and Software 24:173-190. http://dx. doi.org/10.1016/j.envsoft.2008.06.016

Briner, S., C. Elkin, R. Huber, and A. Grêt-Regamey. 2012. Assessing the impacts of economic and climate changes on land-use in mountain regions: a spatial dynamic modeling approach. Agriculture, Ecosystems and Environment 149:50-63. http://dx.doi.org/10.1016/j.agee.2011.12.011

Buttler, A., F. Kohler, and F. Gillet. 2009. The Swiss mountain wooded pastures: patterns and processes. Pages 377-396 in A. Rigueiro-Rodriguez, J. McAdam, and M. R. MosqueraLosada, editors. Agroforestry in Europe: current status and future prospects. Springer, New York, New York, USA. http:// dx.doi.org/10.1007/978-1-4020-8272-6 19

Carpenter, S. R., E. M. Bennett, and G. D. Peterson. 2006. Scenarios for ecosystem services: an overview. Ecology and Society 11(1): 29. [online] URL: http://www.ecologyandsociety. org/vol11/iss1/art29/

Carpenter, S. R., C. Folke, M. Scheffer, and F. Westley. $2009 b$. Resilience: accounting for the noncomputable. Ecology and Society 14(1): 13. [online] URL: http://www.ecologyandsociety. org/vol14/iss1/art13/

Carpenter, S. R., H. A. Mooney, J. Agard, D. Capistrano, R. S. DeFries, S. Diaz, T. Dietz, A. K. Duraiappah, A. OtengYeboah, H. M. Pereira, C. Perrings, W. V. Reid, J. Sarukhan, R. J. Scholes, and A. Whyte. 2009a. Science for managing ecosystem services: beyond the millennium ecosystem assessment. Proceedings of the National Academy of Sciences of the United States of America 106:1305-1312. http://dx.doi. org/10.1073/pnas.0808772106

Chételat, J., M. Kalbermatten, K. S. M. Lannas, T. Spiegelberger, J.-B. Wettstein, F. Gillet, A. Peringer, and A. Buttler. 2013. A contextual analysis of observed land-use and vegetation changes applied to two wooded pastures in the Swiss Jura Mountains. Ecology and Society 18(1): 39. http:// dx.doi.org/10.5751/ES-05287-180139

Claessens, L., J. M. Schoorl, P. H. Verburg, L. Geraedts, and A. Veldkamp. 2009. Modelling interactions and feedback mechanisms between land use change and landscape processes. Agriculture, Ecosystems and Environment 129:157-170. http://dx.doi.org/10.1016/j.agee.2008.08.008

Collins, S. L., S. R. Carpenter, S. M. Swinton, D. E. Orenstein, D. L. Childers, T. L. Gragson, N. B. Grimm, J. M. Grove, S. L. Harlan, J. P. Kaye, A. K. Knapp, G. P. Kofinas, J. J. Magnuson, W. H. McDowell, J. M. Melack, L. A. Ogden, G. P. Robertson, M. D. Smith, and A. C. Whitmer. 2011. An integrated conceptual framework for long-term socialecological research. Frontiers in Ecology and the Environment 9:351-357. http://dx.doi.org/10.1890/100068

Cumming, G. S., D. H. M. Cumming, and C. L. Redman. 2006. Scale mismatches in social-ecological systems: causes, consequences, and solutions. Ecology and Society 11(1): 14. [online] URL: http://www.ecologyandsociety.org/vol11/iss1/ art14/

Daily, G. C., S. Polasky, J. Goldstein, P. M. Kareiva, H. A. Mooney, L. Pejchar, T. H. Ricketts, J. Salzman, and R. Shallenberger. 2009. Ecosystem services in decision making: time to deliver. Frontiers in Ecology and the Environment 7:21-28. http://dx.doi.org/10.1890/080025

Dong, S., L. Wen, S. Liu, X. Zhang, J. P. Lassoie, S. Yi, X. Li, J. Li, and Y. Li. 2011. Vulnerability of worldwide pastoralism to global changes and interdisciplinary strategies for sustainable pastoralism. Ecology and Society 16(2): 10. [online] URL: http://www.ecologyandsociety.org/vol16/iss2/ art10/

Engel, S., S. Pagiola, and S. Wunder. 2008. Designing payments for environmental services in theory and practice: an overview of the issues. Ecological Economics 65:663-674. http://dx.doi.org/10.1016/j.ecolecon.2008.03.011

Ericksen, P. J. 2008. What is the vulnerability of a food system to global environmental change? Ecology and Society 13(2): 14. [online] URL: http://www.ecologyandsociety.org/vol13/ iss $2 / \operatorname{art} 14 /$

European Environmental Agency (EEA). 2010. Europe's ecological backbone: recognising the true value of our mountains. European Environmental Agency, Copenhagen, Denmark. [online] URL: http://www.eea.europa.eu/publications/ europes-ecological-backbone

Figueiredo, J., and H. Pereira. 2011. Regime shifts in a socioecological model of farmland abandonment. Landscape Ecology 26:737-749. http://dx.doi.org/10.1007/s10980-011-9605-3

Folke, C. 2006. Resilience: the emergence of a perspective for social-ecological systems analyses. Global Environmental Change 16:253-267. http://dx.doi.org/10.1016/j. gloenvcha.2006.04.002

Foster, D., F. Swanson, J. Aber, I. Burke, N. Brokaw, D. Tilman, and A. Knapp. 2003. The importance of land-use legacies to ecology and conservation. Bioscience 53:77-88. 
[online] URL: http://www.bioone.org/doi/abs/10.1641/0006-3568\% 282003\%29053\%5B0077\%3ATIOLUL\%5D2.0.CO\%3B2? journalCode $=$ bisi

Fraser, E. D. G., A. J. Dougill, K. Hubacek, C. H. Quinn, J. Sendzimir, and M. Termansen. 2011. Assessing vulnerability to climate change in dryland livelihood systems: conceptual challenges and interdisciplinary solutions. Ecology and Society 16(3): 3. [online] URL: http://www.ecologyandsociety. org/vol16/iss3/art3/ http://dx.doi.org/10.5751/ES-03402-160303

Freeman, L. C. 1979. Centrality in social networks: conceptual clarification. Social Networks 1:215-239. http://dx.doi. org/10.1016/0378-8733(78)90021-7

Gallandat, J.-D., F. Gillet, E. Havlicek, and A. Perrenoud. 1995. Typologie et systémique phytoécologiques des pâturages boisés du Jura suisse. Écologie végétale, Université de Neuchâtel, Institut de Botanique, Neuchâtel, Switzerland. [online] URL: http://www2.unine.ch/lsv/page-5849 fr.html

Gavazov, K. S., A. Peringer, A. Buttler, F. Gillet, and T. Spiegelberger. 2013. Dynamics of forage production in pasture-woodlands of the Swiss Jura Mountains under projected climate change scenarios. Ecology and Society 18 (1): 38. http://dx.doi.org/10.5751/ES-04974-180138

Gibon, A., D. Sheeren, C. Monteil, S. Ladet, and G. Balent. 2010. Modelling and simulating change in reforesting mountain landscapes using a social-ecological framework. Landscape Ecology 25:267-285.

Gillet, F. 2008. Modelling vegetation dynamics in heterogeneous pasture-woodland landscapes. Ecological Modelling 217:1-18. http://dx.doi.org/10.1016/j.

ecolmodel.2008.05.013

Grimm, V., U. Berger, F. Bastiansen, S. Eliassen, V. Ginot, J. Giske, J. Goss-Custard, T. Grand, S. K. Heinz, G. Huse, A. Huth, J. U. Jepsen, C. Jorgensen, W. M. Mooij, B. Müller, G. Pe'er, C. Piou, S. F. Railsback, A. M. Robbins, M. M. Robbins, E. Rossmanith, N. Rüger, E. Strand, S. Souissi, R. A. Stillman, R. Vaboø, U. Visser, and D. L. DeAngelis. 2006. A standard protocol for describing individual-based and agent-based models. Ecological Modelling 198:115-126. http://dx.doi. org/10.1016/j.ecolmodel.2006.04.023

Grimm, V., U. Berger, D. L. DeAngelis, J. G. Polhill, J. Giske, and S. F. Railsback. 2010. The ODD protocol: a review and first update. Ecological Modelling 221:2760-2768. http://dx. doi.org/10.1016/j.ecolmodel.2010.08.019

Hanley, N., S. Acs, M. Dallimer, K. J. Gaston, A. Graves, J. Morris, and P. R. Armsworth. 2012. Farm-scale ecological and economic impacts of agricultural change in the uplands. Land Use Policy 29:587-597. http://dx.doi.org/10.1016/j. landusepol.2011.10.001
Happe, K., A. Balmann, K. Kellermann, and C. Sahrbacher. 2008. Does structure matter? The impact of switching the agricultural policy regime on farm structures. Journal of Economic Behavior and Organization 67:431-444. http://dx. doi.org/10.1016/j.jebo.2006.10.009

Happe, K., K. Kellermann, and A. Balmann. 2006. Agentbased analysis of agricultural policies: an illustration of the agricultural policy simulator AgriPoliS, its adaptation, and behavior. Ecology and Society 11(1): 49. [online] URL: http:// www.ecologyandsociety.org/vol11/iss1/art49/

He, H. S., B. E. DeZonia, and D. J. Mladenoff. 2000. An aggregation index (AI) to quantify spatial patterns of landscapes. Landscape Ecology 15:591-601.

Heckbert, S., T. Baynes, and A. Reeson. 2010. Agent-based modeling in ecological economics. Annals of the New York Academy of Sciences 1185:39-53. http://dx.doi.org/10.1111/ j.1749-6632.2009.05286.x

Hirschi, C., A. Widmer, S. Briner, and R. Huber. 2013. Combining policy network and model-based scenario analyses: an assessment of future ecosystem goods and services in Swiss mountain regions. Ecology and Society 18 (2): 42. http://dx.doi.org/10.5751/ES-05480-180242

Huber, R., H. Bugmann, A. Buttler, and A. Rigling. $2013 a$. Sustainable land-use practices in European mountain regions under global change: an integrated research approach Ecology and Society 18(3) in press.

Huber, R., A. Rigling, P. Bebi, F. Simon Brand, S. Briner, A. Buttler, C. Elkin, F. Gillet, A. Grêt-Regamey, C. Hirschi, H. Lischke, R. Werner Scholz, R. Seidl, T. Spiegelberger, A. Walz, W. Zimmermann, and H. Bugmann. 2013b. Sustainable land use in mountain regions under global change: synthesis across scales and disciplines. Ecology and Society 18(3) in press.

Huber, R., M. Hunziker, and B. Lehmann. 2011. Valuation of agricultural land-use scenarios with choice experiments: a political market share approach. Journal of Environmental Planning and Management 54:93-113.

Intergovernmental Panel on Climate Change (IPCC). 2000. Emissions scenarios - summary for policymakers. IPCC Working Group III, Intergovernmental Panel on Climate Change, Geneva, Switzerland.

Jack, B. K., C. Kousky, and K. R. E. Sims. 2008. Designing payments for ecosystem services: lessons from previous experience with incentive-based mechanisms. Proceedings of the National Academy of Sciences 105:9465-9470. http://dx. doi.org/10.1073/pnas.0705503104

Keenleyside, C., and G. M. Tucker. 2010. Farmland abandonment in the EU: an assessment of trends and 
prospects. Report Prepared for WWF, Institute for European Environmental Policy, London, UK. [online] URL: http:// www.ieep.eu/assets/733/Farmland abandonment in the EU _assessment_of_trends_and_prospects__.FINAL_15-11-2010_. pdf

Kinzig, A. P., C. Perrings, F. S. Chapin, III, S. Polasky, V. K. Smith, D. Tilman, and B. L. Turner, II. 2011. Paying for ecosystem services: promise and peril. Science 334:603-604. http://dx.doi.org/10.1126/science.1210297

Knoke, D. 2011. Policy networks. Pages 210-222 in J. Scott and P. Carrington, editors. The Sage handbook of social network analysis. Sage, London, UK.

Lauber, S. 2006a. Agrarstrukturwandel im berggebiet. Dissertation. Eidgenössischen Technical University, Zürich, Switzerland. [online] URL: http://e-collection.library.ethz.ch/ eserv/eth:29031/eth-29031-02.pdf

Lauber, S. 2006b. Path-dependent change in agricultural structure in two mountain areas in Switzerland: a spatially explicit modelling approach. Pages 77-97 in S. Mann, editor. Causes and impacts of agricultural structures. Nova Science, New York, New York, USA.

Lanz, S. 2012. Main aspects of the agricultural policy for 2014-2017. Swiss Federal Department of Economic Affairs (FDEA) and Federal Office for Agriculture (FOAG), Berne, Switzerland. [online] URL: http://www.blw.admin.ch/ aktuell/index.html?lang=en

Le, Q. B., S. J. Park, and P. L. G. Vlek. 2010. Land use dynamic simulator (LUDAS): a multi-agent system model for simulating spatio-temporal dynamics of coupled human landscape system: 2. Scenario-based application for impact assessment of land-use policies. Ecological Informatics 5:203-221. http://dx.doi.org/10.1016/j.ecoinf.2010.02.001

Le, Q. B., S. J. Park, P. L. G. Vlek, and A. B. Cremers. 2008. Land-use dynamic simulator (LUDAS): a multi-agent system model for simulating spatio-temporal dynamics of coupled human landscape system. I. Structure and theoretical specification. Ecological Informatics 3:135-153. http://dx. doi.org/10.1016/j.ecoinf.2008.04.003

Liu, J., T. Dietz, S. R. Carpenter, M. Alberti, C. Folke, E. Moran, A. N. Pell, P. Deadman, T. Kratz, J. Lubchenco, E. Ostrom, Z. Ouyang, W. Provencher, C. L. Redman, S. H. Schneider, and W. W. Taylor. 2007. Complexity of coupled human and natural systems. Science 317:1513-1516. http://dx. doi.org/10.1126/science.1144004

Marini, L., S. Klimek, and A. Battisti. 2011. Mitigating the impacts of the decline of traditional farming on mountain landscapes and biodiversity: a case study in the European Alps. Environmental Science and Policy 14:258-267. http://dx.doi. org/10.1016/j.envsci.2010.12.003
Matthews, R. B., N. G. Gilbert, A. Roach, J. G. Polhill, and N. M. Gotts. 2007. Agent-based land-use models: a review of applications. Landscape Ecology 22:1447-1459.

Millennium Ecosystem Assessment (MEA). 2005. Ecosystems and human well-being: synthesis. Island Press, Washington, D.C., USA.

Müller, F., R. de Groot, and L. Willemen. 2010. Ecosystem services at the landscape scale: the need for integrative approaches. Landscape Online 23:1-11. [online] URL: http:// www.landscapeonline.de/archive/2010/23/Mueller etal LO23 2011. pdf

Organisation for Economic Co-operation and Development (OECD). 2010. Agricultural policies in OECD countries 2010. OECD Publishing, Paris, France.

Ostrom, E. 2009. A general framework for analyzing sustainability of social-ecological systems. Science 325:419-422. http://dx.doi.org/10.1126/science.1172133

Parker, D. C., S. M. Manson, M. A. Janssen, M. J. Hoffmann, and P. Deadman. 2003. Multi-agent systems for the simulation of land-use and land-cover change: a review. Annals of the Association of American Geographers 93:314-337.

Pereira, H. M., P. W. Leadley, V. Proença, R. Alkemade, J. P. W. Scharlemann, J. F. Fernandez-Manjarrés, M. B. Araújo, P. Balvanera, R. Biggs, W. W. L. Cheung, L. Chini, H. D. Cooper, E. L. Gilman, S. Guénette, G. C. Hurtt, H. P. Huntington, G. M. Mace, T. Oberdorff, C. Revenga, P. Rodrigues, R. J. Scholes, U. R. Sumaila, and M. Walpole. 2010. Scenarios for global biodiversity in the 21 st century. Science 330:1496-1501. http://dx.doi.org/10.1126/science.1196624

Peringer, A., S. Siehoff, J. Chételat, T. Spiegelberger, A. Buttler, and F. Gillet. 2013. Past and future landscape dynamics in pasture-woodlands of the Swiss Jura mountains under climate change. Ecology and Society 18(3) in press.

Roeder, N., D. Lederbogen, J. Trautner, A. Bergamini, S. Stofer, and C. Scheidegger. 2010. The impact of changing agricultural policies on jointly used rough pastures in the Bavarian Pre-Alps: an economic and ecological scenario approach. Ecological Economics 69:2435-2447. http://dx.doi. org/10.1016/j.ecolecon.2010.07.013

Rounsevell, M. D. A., B. Pedroli, K.-H. Erb, M. Gramberger, A. G. Busck, H. Haberl, S. Kristensen, T. Kuemmerle, S. Lavorel, M. Lindner, H. Lotze-Campen, M. J. Metzger, D. Murray-Rust, A. Popp, M. Pérez-Soba, A. Reenberg, A. Vadineanu, P. H. Verburg, and B. Wolfslehner. 2012. Challenges for land system science. Land Use Policy 29:899-910. http://dx.doi.org/10.1016/j.landusepol.2012.01.007

Sandström, A., and L. Carlsson. 2008. The performance of policy networks: the relation between network structure and 
network perfomance. Policy Studies Journal 36:497-524. http://dx.doi.org/10.1111/j.1541-0072.2008.00281.x

Scholz, R. W. 2011. Environmental literacy in science and society: from knowledge to decisions. Cambridge University Press, Cambridge, UK.

Schreinemachers, P., and T. Berger. 2011. An agent-based simulation model of human-environment interactions in agricultural systems. Environmental Modelling and Software 26:845-859. http://dx.doi.org/10.1016/j.envsoft.2011.02.004

Serdült, U., and C. Hirschi. 2004. From process to structure: developing a reliable and valid tool for policy network comparison. Swiss Political Science Review 10:137-155. http://dx.doi.org/10.1002/j.1662-6370.2004.tb00026.x

Sitzia, T., and G. Trentanovi. 2011. Maggengo meadow patches enclosed by forests in the Italian Alps: evidence of landscape legacy on plant diversity. Biodiversity and Conservation 20:945-961.

Sommerville, M. M., J. P. G. Jones, and E. J. Milner-Gulland. 2009. A revised conceptual framework for payments for environmental services. Ecology and Society 14(2): 34. [online] URL: http://www.ecologyandsociety.org/vol14/iss2/ $\underline{\operatorname{art} 34 /}$

Steffen, W. 2009. Interdisciplinary research for managing ecosystem services. Proceedings of the National Academy of Sciences 106:1301-1302. http://dx.doi.org/10.1073/pnas.0812580106

Valbuena, D., P. H. Verburg, A. K. Bregt, and A. Ligtenberg. 2010. An agent-based approach to model land-use change at a regional scale. Landscape Ecology 25:185-199.

Verboom, J., R. Alkemade, J. Klijn, M. J. Metzger, and R. Reijnen. 2007. Combining biodiversity modeling with political and economic development scenarios for $25 \mathrm{EU}$ countries. Ecological Economics 62:267-276. http://dx.doi. org/10.1016/j.ecolecon.2006.04.009

Verburg, P. H., D. B. van Berkel, A. M. van Doorn, M. van Eupen, and H. A. R. M. van den Heiligenberg. 2010. Trajectories of land use change in Europe: a model-based exploration of rural futures. Landscape Ecology 25:217-232.

Wallman, P., M. G. E. Svensson, H. Sverdrup, and S. Belyazid. 2005. ForSAFE - an integrated process-oriented forest model for long-term sustainability assessments. Forest Ecology and Management 207:19-36. http://dx.doi.org/10.1016/j.

foreco.2004.10.016

Wasserman, S., and K. Faust. 1994. Social network analysis: methods and applications. Cambridge University Press, Cambridge, UK.
Widmer, T., C. Hirschi, U. Serdült, and C. Vögeli. 2008. Analysis with APES, the actor process event scheme. Pages 150-171 in M. M. Bergmann, editor. Advances in mixed methods research: theories and applications. Sage, Los Angeles, California, USA.

World Trade Organization (WTO). 2011. Understanding the WTO: the agricultural agreement: new rules and commitments. World Trade Organization, Geneva, Switzerland. [online] URL: http://www.wto.org/english/thewto_e/whatis_e/ tif_e/agrm3_e.htm

Wunder, S., S. Engel, and S. Pagiola. 2008. Taking stock: a comparative analysis of payments for environmental services programs in developed and developing countries. Ecological Economics 65:834-852. http://dx.doi.org/10.1016/j. ecolecon.2008.03.010

Zimmermann, P., E. Tasser, G. Leitinger, and U. Tappeiner. 2010. Effects of land-use and land-cover pattern on landscapescale biodiversity in the European Alps. Agriculture, Ecosystems and Environment 139:13-22. http://dx.doi. org/10.1016/j.agee.2010.06.010 


\section{Modeling Social-Ecological Feedback Effects in the Implementation of Payments for Environmental Services in Pasture-Woodlands}

\section{ODD PROTOCOL FOR ALUAM-AB}

\section{Purpose}

The purpose of ALUAM-AB is to understand agricultural landuse changes triggered by market and policy changes giving due considering to the individual preferences of the farmers. The consequences of changes in prices and policy measures relating to agricultural land-use activities can be simulated. With respect to this study, spatially explicit information on agricultural activities (spatially explicit stock density change) allows for a viable linkage with the vegetation model WoodPaM.

\section{State variables and scale}

Agents represent individual farms. A farm agent has (1) its own state which is updated after every simulation period of one year and (2) decision-making mechanisms for managing farm resources. The state of the farm agent includes variables for household composition and available resources (land, capital and labor) and household preferences for agricultural activities. Information on preferences for agricultural activities, household composition and available resources was compiled in individual interviews with the farmers (see Table A2). Important parameters with respect to the individual characteristics of the farmers are: the point in time of their retirement (65 years), whether or not they have a successor (succession), their intention to increase farm size (growth), their willingness to take part in agrienvironmental schemes (extensification), their preferences concerning specific production activities e.g. milk production is preferred to meat production despite lower income (activity change), and their demand for leisure time (result from the questionnaire's comment section). The interviews also allowed for the identification of the mosaic of paddocks per farm and in the whole case study region.

The smallest landscape unit in ALUAM-AB is the paddock as it is used by the individual farmer. A higher resolution of the model would not provide additional information since land-use activities are homogenous on these paddocks and the representation of vegetation dynamics in WoodPaM would not be improved. Since WoodPaM models vegetation on a higher spatial resolution of $25 \mathrm{~m}^{2}$ these parcels are aggregated to the level of the current paddocks for a transfer between the models. In contrast, with a lower resolution (e.g. at farm level) important information with respect to land-use intensity would be lost.

Natural conditions of the different paddocks and potential fodde production are integrated using results of the vegetation model WoodPaM. In WoodPaM, a paddock is represented by an arrangement of square grid cells, each $25 \mathrm{~m}$ wide. Each cell features four compartments: i) the herb layer (consisting of four ecological community types: eutrophic pastureland, oligotrophic pastureland, fallow and understory), ii) shrubs, iii) trees (13 species, divided into four life stages: seedlings, saplings, small trees and big mature trees), iv) cattle. Local succession in the herb layer is driven by local intensity of grazing, trampling, dunging and shading. Local woody plant succession is driven by seeding input, safe-site availability in the herb layer and browsing intensity. Local successions within cells are influenced by neighboring cells through seed dispersal from trees (von Neumann connectivity) and are connected at paddock level by cattle behavior. Selective habitat use by cattle among cells within each paddock considers the attractiveness of each cell, which depends on local forage production, distance to watering points, tree cover and geomorphology. The following land and soil characteristics are used as input for each paddock: altitude, slope, aspect, rock outcrops, soil depth, carbon and nutrient cycling rates, past and current vegetation, climatic data and scenarios based on observed data from 1901 to 2000 (interpolated monthly temperature and precipitation) and expected driving parameters according to IPCC scenarios.

Agronomic variables include yield losses, plant nutrient requirements $(\mathrm{N}, \mathrm{P})$, manure production and production coefficients such as fodder intake, growth, birth, deaths of animals, or labor requirements etc. that are based on Swiss average data (Briner et al. 2012). Production related variables, e.g. the number of livestock or the amount of hay sold, are aggregated at farm level and represent aggregated values over one year. In the optimization process, these variables are optimized under the consideration of different balances that link land-use activities with livestock activities: fodder and nutrient balances. As a result, land-use intensities are defined in a spatially explicit manner.

Given the focus on individual farmers, the temporal scale of the model is limited to 15-25 years in our approach. Scenario parameters for prices and costs were derived from project-based context scenarios. These are consistent with the base assumptions of the existing set of global greenhouse gas emission scenarios (IPCC SRES) and thus with the climate simulation data used for model-based impact assessment (Walz et al. 2012). The effective data followed the development presented in Abildtrup et al. (2006).

\section{Process overview and scheduling}

ALUAM-AB proceeds in annual time steps. The agents allocate their available resources in order to maximize their income (aggregated land rent from the specific paddocks). Thereby they consider natural, farm level and individual constraints as well as incentives and regulations from the market and policy instruments. Investments in production capacity made in previous years are considered as sunk costs representing path dependencies on the individual farms.

Structural change is modeled using a land market sub-model based on Lauber (2006a). The model determines paddocks that are no longer cultivated under the existing farm structure. There are 3 main reasons why paddocks are attributed to the landmarket: i) paddocks generate a land rent below zero, ii) the corresponding owner of the farm does not reach a minimum wage of 30'000 Swiss Francs per year, therefore the farm is abandoned and all the assigned land enters the land market or iii) the farmer retires in the simulation year and has no successor, thus all his land goes onto the market (Figure A1).

The land market sub-model randomly assigns the paddocks to one of the other farms. It is then checked to confirm that this farm shows the two following characteristics: the farmer receiving the paddock must want to expand his cultivated area (willingness to grow) and his shadow price for the land must be positive. If these conditions are not met, the paddock is returned to the land market and assigned randomly to another farm. Once again it is checked to verify that this farm fulfils the conditions for the assignment of the paddock. This procedure is repeated until all the paddocks are assigned to a farm or none of the farms is willing to take the paddocks left on the market. Paddocks that are not transferred to other farms are defined as abandoned. Natural vegetation dynamics get under way on these paddocks (explicitly modeled in WoodPaM). If land-use allocation at farm level is optimal (both from an economic and individual perspective), farm equipment, capacities and livestock are updated and the next annual time step is initialized using the parameters (prices, costs) of the following year. In this step, the modifications due to climatic and management changes calculated in WoodPaM are used to update the spatially explicit yield potential in ALUAM-AB.

The interaction between ALUAM-AB and WoodPaM is modeled in the following sequence: while each model is driven by (synchronized) time series of climate or agronomic constraints, farm structural change is passed from ALUAM-AB to WoodPaM in terms of stocking density per paddock and vegetation response is transferred from WoodPaM to ALUAM-AB in terms of forage productivity of the paddocks. This data exchange occurs for time steps of 5 years, starting in the year 2000 .

This means there is a time lag in model coupling, according to the following protocol: during each 5 year period, ALUAM-AB uses the average annual forage production of paddocks, as simu- 
lated by WoodPaM during the preceding period, to simulate yearly livestock allocation per paddock for 5 years, giving due consideration to contemporary socio-economic constraints of farms, but with temporally constant forage productivity. After that, WoodPaM uses the yearly time series of stocking densities per paddock and simulates vegetation response, from which the average productivity of paddocks during the current period is calculated, giving due consideration to climatic variability. Productivity is transferred back to ALUAM-AB as the input variable for the following 5-years-period, thus closing the local feedback loop.

We follow this protocol from 2000 until 2034, where reliable predictions of agronomic developments end. Since ALUAM-AB is based on the characteristics of the current farmers, the model is discontinued in 2034. However, given the large temporal gap between the establishment of tree seedlings and the formation of forest stands, the combined effects of land- use and climate on landscape structure can only be shown in a timeframe of at least a few tree generations. Thus, we prolong WoodPaM simulations until the end of currently available projections for climate change (i.e. 2100), assuming that land-use intensity simulated for year 2034 will be constant until 2100 . These exploratory simulations pinpoint the potential, long-term consequences of today's landuse decisions.

\section{Design concepts}

Emergence

Structural change on farm level emerges from an endogenous development that is determined by prices, policies and individua preferences which are given exogenously. In addition, land-use patterns (intensity levels of land-use) emerge from the main outcome of the structural changes on farm level.

\section{Adaptation}

Farmers respond to climatic, socio-economic and policy changes by adjusting their production activities, applying new production technologies, increasing (or reducing) land size and adjusting land-use intensities. In addition, farmers also exit the sector if their income falls below a certain limit (30’000 Swiss Francs).

Objectives and prediction

The agent's objectives are characterized by a whole farm income optimization approach that governs the allocation of an agent's available resources to production considering natural, farm-level and individual constraints as well as incentives and regulations from the market (yearly price and cost parameters) and policy scenarios. Thus, the fundamental concept behind our approach is rational economic behavior (land rent maximization). However, the consideration of individual constraints, such as personal preferences and attitudes towards production activities and individual expectations concerning leisure time and well-being, leads to the inclusion of non-economic goals in the decisionmaking process (Lauber 2006a, b).

Agent-environment interaction and observation

The interaction between the farmers and the environment is based on the model linkage of WoodPaM and ALUAM-AB. Detailed information on spatially explicit natural conditions (e.g. grassland yields) are provided by the WoodPaM model (Gillet 2008, Peringer et al. 2012). The corresponding maps are used as an input for ALUAM-AB. The spatially explicit information following the optimization procedure is then re-entered into the vegetation model. These maps can be used to illustrate the changes in land-use dynamics.

\section{Initialization}

Initial attributes for households were defined using information from the interviews along with farm census data of the FOAG. In addition, the modeling results from WoodPaM were used to calibrate existing land-use intensities on paddock level. The corresponding results were verified with local experts (Chételat et al. 2012). The validation of the ALUAM-AB model showed satisfying results with respect to livestock numbers, farm structures and income.

Input

Information with respect to natural conditions is derived from the WoodPaM model. Price and cost developments are derived from scenarios for the European agricultural sector (Abildtrup et al. 2006). Policy and climate changes follow from an interdisciplinary development of scenarios for our case study region (Walz et al. 2012).

\section{Sub-models}

ALUAM-AB consists of individual farms which are modeled again using different sub-models for plant activities and livestock activities. A detailed description of these sub-models can be found in Briner et al. 2012. The summary of ALUAM-AB submodels is shown in Table A1.

\section{Link to OpenABM}

http://www.openabm.org/model/2870/version/2/view

\section{Literature cited}

Abildtrup, J., E. Audsley, M. Fekete-Farkas, C. Giupponi, M. Gylling, P. Rosato, and M. Rounsevell. 2006. Socio-economic scenario development for the assessment of climate change impacts on agricultural land use: a pairwise comparison approach. Environmental Science \& Policy 9:101-115.

Briner, S., R. Huber, C. Elkin, and A. Grêt-Regamey. 2012. Assessing the impacts of economic and climate changes on landuse in mountain regions: A spatial dynamic modeling approach. Agriculture, Ecosystems \& Environment 149:50-63.

Chételat, J., T. Kalbermatten, K. Lannas, T. Spiegelberger, J.-B. Wettstein, F. Gillet, A. Peringer, and A. Buttler. 2012. A contextual analysis of observed land-use and vegetation changes applied to two wooded pastures in the Swiss Jura Mountains. Ecology and Society 18(1): 39. http://dx.doi.org/10.5751/ES05287-180139

Gillet, F. 2008. Modelling vegetation dynamics in heterogeneous pasture-woodland landscapes. Ecological Modelling 217:1-18.

Lauber, S. 2006a. Agrarstrukturwandel im Berggebiet. ART Schriftenreihe. Dissertation ETH Nr.16716, Zürich. [online] URL: http://e-collection.library.ethz.ch/view/eth:29031.

Lauber, S. 2006b. Path-Dependent Change in Agricultural Structure in Two Mountain Areas in Switzerland. A Spatially Explicit Modelling Approach. Pages 77-97 in S. Mann, editor. Causes and Impacts of Agricultural Structures. Nova Science Publishers, New York.

Peringer, A., S. Siehoff, J. Chételat, T. Spiegelberger, A. Buttler, and F. Gillet. 2012. Past and future landscape dynamics in wooded pastures of the Jura Mountains under land-use and climate change. Ecology and Society (in press).

Walz, A., J. Braendle, D. J. Lang, F. Brand, S. Briner, C. Elkin, C. Hirschi, R. Huber, H. Lischke, and D. R. Schmatz. 2012 Experience from customising IPCC scenarios to specific national-level focus scenarios for ecosystem service management. Technological Forecasting and Social Change (accepted). 


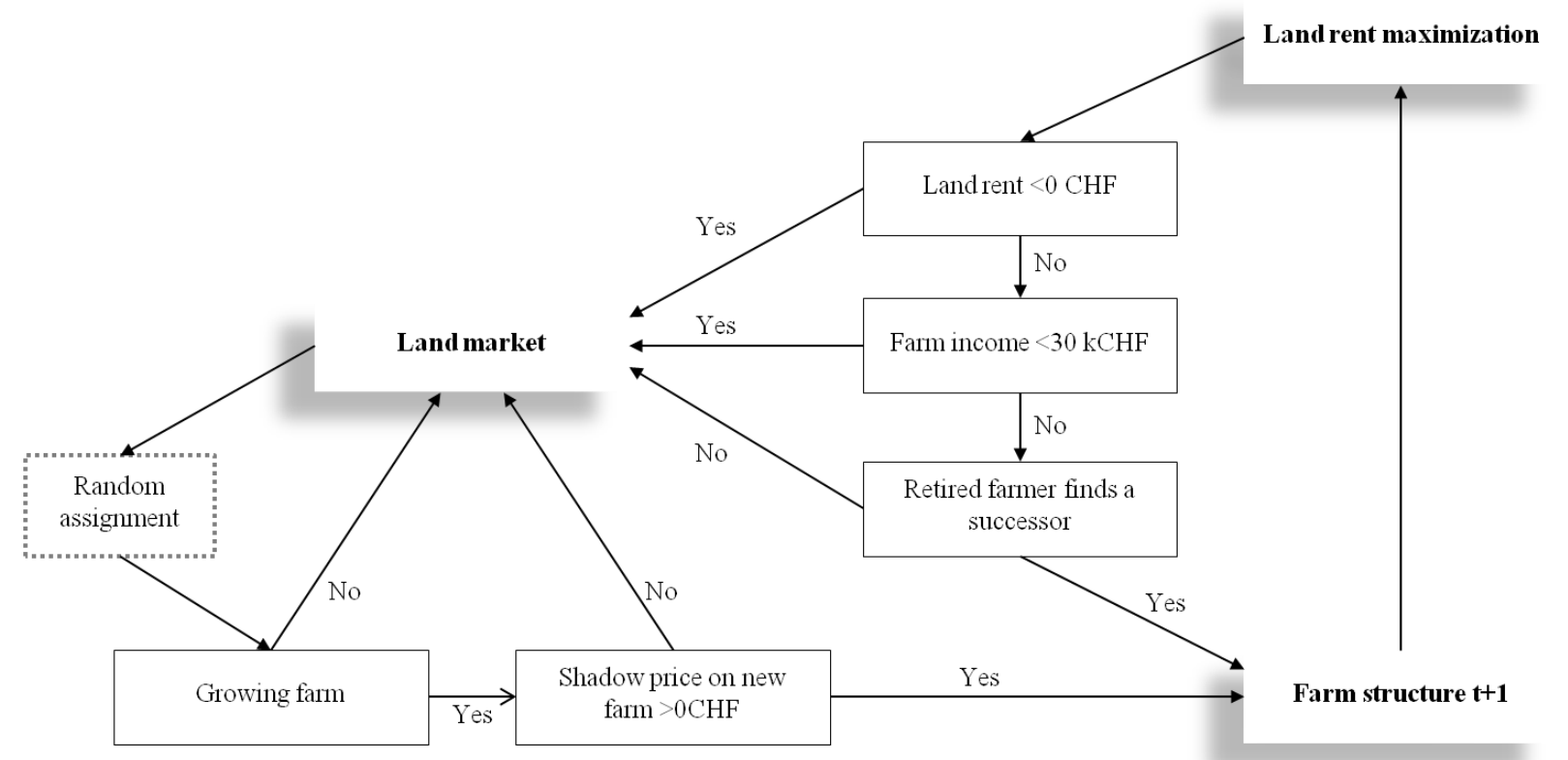

Table A1: Short description of the ALUAM-AB sub-models

\begin{tabular}{lll}
\hline \hline Sub-model & $\begin{array}{l}\text { Agent or natural ob- } \\
\text { ject/system involved }\end{array}$ & Function \\
\hline Plant production sub-model & $\begin{array}{l}\text { Agricultural land- use } \\
\text { activities }\end{array}$ & $\begin{array}{l}\text { Represents fodder and crop production systems. Reconciles natural plant } \\
\text { development (yields, nutrient input, etc.), farm technology (harvest tech- } \\
\text { nology, labor, etc.) and resulting returns and costs per output unit (kg of } \\
\text { crop). }\end{array}$ \\
& Livestock activities & $\begin{array}{l}\text { Represents the livestock production system on farm level. Calculation of in- } \\
\text { and output for different livestock activities including dairy and suckler } \\
\text { cows, calves, cattle and others. Considers production inputs and farm } \\
\text { technology (including labor) as well as farm structures (buildings). Returns } \\
\text { and costs per output unit (milk, meat) are calculated. }\end{array}$
\end{tabular}

Integrating agronomic sub-model Agricultural activities

Agent decision sub-model

Farm agents

Environmental sub-models

Land market sub-model

WoodPAM (optional)
Agricultural activities

Land units (paddocks)

Land units (paddocks)
Balances the supply and demand for roughage and nutrients on farm level; links the livestock with the plant production sub-model.

The decision of the different agents is based on a constrained income maximization organized in an objective function and a set of constraints which define the solution space formally written as

$$
\begin{array}{cc}
Z=\sum_{j}\left(p_{j}-c_{j}\right) \cdot x_{j} & \\
\sum_{j} a_{i j} \cdot x_{j} \leq b_{i} & \forall i=1 \ldots I \\
x_{j} \geq 0 & \forall j=1 \ldots J
\end{array}
$$

$\mathrm{Z}=$ income per farmer

$\mathrm{X}_{\mathrm{j}}=$ agricultural farm activity $(\mathrm{j}=1$ to $\mathrm{I})$

$\mathrm{p}_{\mathrm{j}}=$ returns of activity $\mathrm{j}$

$\mathrm{c}_{\mathrm{j}}=$ cost per activity $\mathrm{j}$

$\mathrm{a}_{\mathrm{ij}}=$ technical coefficients required to produce $\mathrm{x}_{\mathrm{j}}$ (of constraint $\mathrm{i}$ and activity

j)

$b_{\mathrm{ij}}=$ available resource

All activities $\mathrm{x}_{\mathrm{j}}$ are non-negative.

Individual resource constraints $\left(\mathrm{b}_{\mathrm{ij}}\right)$ are defined for each agent based on Table A2. E.g. if the farmer stated that leisure time is an objective, the availability of work was a constraint in the corresponding agent.

Calculations of nitrogen (N) and greenhouse gas (GHG) emissions based on coefficients for each activity.

Distributes abandoned land among the remaining farms (see Figure A1). Agents are limited to farm expansion if the farmer is unwilling to increase farm size.

Calculates spatially explicit fodder yields in the different paddocks based on i) current land-use, ii) natural site conditions (soil and climate) and iii) stocking density. Yields are integrated via the plant sub-model. 
Table A2: Characteristics of farms in 2011

\begin{tabular}{|c|c|c|c|c|c|c|c|}
\hline Name & $\begin{array}{c}\text { Les Planets } \\
\text { Ouest }\end{array}$ & $\begin{array}{c}\text { Les Planets } \\
\text { Milieu Ouest }\end{array}$ & $\begin{array}{c}\text { Les Planets } \\
\text { Milieu Est }\end{array}$ & Les Planets Est & $\begin{array}{l}\text { Les Cluds } \\
\text { Sud } \\
\end{array}$ & $\begin{array}{l}\text { Les Cluds } \\
\text { Nord }\end{array}$ & $\begin{array}{c}\text { La Bullatone } \\
\text { Dessous }\end{array}$ \\
\hline Farm size (ha) & 65 & 31 & 32 & 49 & 60 & 55 & 47 \\
\hline Number of cows & 33 & 16 & 20 & 26 & 40 & 18 & 47 \\
\hline $\begin{array}{l}\text { Free capacity } \\
\text { (GVE) }\end{array}$ & No & No & 4 & 12 & 10 & - & No \\
\hline Milk (kg/year) & $226^{\prime} 000$ & 103 '000 & $135^{\prime} 000$ & $149^{\prime} 000$ & - & - & $310^{\prime} 000$ \\
\hline Meat production & & & & & Suckler cows & $\begin{array}{c}\text { Fattening } \\
\text { Calves }\end{array}$ & \\
\hline $\begin{array}{l}\text { Breeding (num- } \\
\text { ber of cattle) }\end{array}$ & No & Yes (8) & Yes (10) & Yes (13) & No & Yes & Yes (15) \\
\hline Summering & No & $\begin{array}{l}\text { Yes (breed- } \\
\text { ing) }\end{array}$ & $\begin{array}{l}\text { Yes (breed- } \\
\text { ing) }\end{array}$ & Yes (breeding) & $\begin{array}{l}15 \text { suckler } \\
\text { cows }\end{array}$ & Yes & $\begin{array}{l}\text { Yes (all dairy } \\
\text { cows) }\end{array}$ \\
\hline $\begin{array}{l}\text { Other animals } \\
\text { (number) }\end{array}$ & No & No & No & $\begin{array}{c}\text { Bull fattening } \\
\text { (5) }\end{array}$ & 13 horses & $\begin{array}{l}\text { Calf fatten- } \\
\text { ing }\end{array}$ & $\begin{array}{l}\text { Bull fattening } \\
\text { (20) }\end{array}$ \\
\hline $\begin{array}{l}\text { Age of farmer } \\
\text { (years) }\end{array}$ & 50 & 53 & 61 & 42 & 31 & 38 & 40 \\
\hline $\begin{array}{l}\text { Additional work- } \\
\text { force }\end{array}$ & Wife (50\%) & Wife $(50 \%)$ & Wife (50\%) & Wife $(30 \%)$ & $\begin{array}{l}\text { Wife }(50 \%) \\
\text { Apprentice }\end{array}$ & - & $\begin{array}{c}\text { Wife }(10 \%) \\
\text { Brother } \\
(100 \%)\end{array}$ \\
\hline $\begin{array}{l}\text { Work outside } \\
\text { agriculture }\end{array}$ & No & No & No & Yes $(30 \%)$ & Yes $(40 \%)$ & - & Yes $(20 \%)$ \\
\hline Extensification & Yes & Yes & No & $\begin{array}{l}\text { No (no direct } \\
\text { payment } \\
\text { optimization) }\end{array}$ & $\begin{array}{l}\text { Yes (even } \\
\text { organic) }\end{array}$ & $\begin{array}{l}\text { Is already } \\
\text { organic }\end{array}$ & No \\
\hline Activity change & No & No & No & Yes & No & No & No, only milk \\
\hline Growth & $\begin{array}{l}\text { No growth in } \\
\text { milk produc- } \\
\text { tion, no land } \\
\text { claims }\end{array}$ & $\begin{array}{l}\text { No land } \\
\text { claims }\end{array}$ & $\begin{array}{l}\text { No growth in } \\
\text { milk produc- } \\
\text { tion, no land } \\
\text { claims }\end{array}$ & $\begin{array}{l}\text { Milk and land } \\
\text { if possible }\end{array}$ & $\begin{array}{c}\text { No more } \\
\text { animals but } \\
\text { land claims if } \\
\text { close to farm }\end{array}$ & No & $\begin{array}{c}\text { Conditional } \\
\text { (investment } \\
\text { and quality of } \\
\text { soil) }\end{array}$ \\
\hline Succession & No & No & No & $\begin{array}{l}\text { (retired in } \\
2034)\end{array}$ & $\begin{array}{l}\text { (retired in } \\
2045)\end{array}$ & No & $\begin{array}{c}\text { (retired in } \\
\text { 2032) } \\
\text { Sons are } \\
\text { interested }\end{array}$ \\
\hline Comments & $\begin{array}{l}\text { Leisure time } \\
\text { as objective }\end{array}$ & $\begin{array}{c}\text { Ecology is } \\
\text { important } \\
\text { (without } \\
\text { label) }\end{array}$ & No future & $\begin{array}{c}\text { Leisure time as } \\
\text { objective }\end{array}$ & $\begin{array}{l}\text { Leisure time } \\
\text { as objective }\end{array}$ & - & (210 \\
\hline
\end{tabular}

